\title{
Integrating Social Media Technologies In Higher Education: Costs-Benefits Analysis
}

Ephraim Okoro, Howard University, USA

\begin{abstract}
Social networking and electronic channels of communication are effective tools in the process of teaching and learning and have increasingly improved the quality of students' learning outcomes in higher education in recent years. The process encourages students' active engagement, collaboration, and participation in class activities and group work, and provides a flow of information dissemination in a sophisticated method that yields measurable results. Faculty can monitor collaborative and independent activities of their students and can also provide timely feedback. Studies identified some issues associated with social networking and students' learning ability, but argue that performance assessment and learning outcomes can be adequately managed as a result of social networking mechanism.
\end{abstract}

This paper concludes that electronic media enhance collaborative learning activities, enabling students to engage in an ongoing communication with one another in the process of learning. Effective use of social networking tools in learning environments by faculty can sustain the quality of instructions and skills-development in business education.

Keywords: Social networking; Social media; Electronic Communication; Collaborative Learning; Independent Learning

\section{INTRODUCTION}

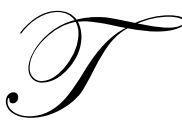

he development of a social networking system has been a dominant trend in teaching and learning environments for some time. This technological innovation was well designed to support teaching and learning and has attracted much scholarly attention in several journals. Researchers across academic disciplines (Warren, 2010; Wandel, 2007; Santovec, 2006) emphasize that rapid development of communication processes, electronic media, and technological processes have improved the quality of teaching and learning in colleges and universities in recent years. Students learn better, work independently and collaboratively, and acquire self-discipline as a result of social networking and personal engagement (Zhao \& Kuh, 2004). Additionally, faculty members perform efficiently, demonstrate outstanding pedagogical commitment in an engaged and demanding learning environment in which they can measure learning outcomes (Hakane, Bakker, \& Schaufeli, 2006). For several years, electronic social networks have facilitated teaching and learning and have also increased the level of faculty and student enthusiasm and interests in the learning activities. Some studies (Magnoler \& Giannandrea, 2008; Suskie, 2004; Young, 2002) indicate a positive correlation between social networking and students' enduring interest in knowledge acquisition. Therefore, it is not surprising that social networking sites have increasingly sustained and improved the methodology of interactions in academic and professional settings. Evidently, the discovery of these systems of communication (Facebook, LinkedIn, MySpace, Blackboard) have transformed the landscape of interpersonal and group communication and have largely minimized the need for faceto-face meetings and discussions in teaching and learning.

The impact of social networking on the learning process is widespread and strongly supported. Selwyn (2009) acknowledges the mixed feelings with which the system has been received since its inception, especially on students' learning outcome. Selwyn determines that "Fears abound within some sections of the educational community that social networking sites could contribute to the intellectual and scholarly de-powering of a 'Google Generation' of learners incapable of independent critical thought and generally hasten the onset of what Ziegler has 
termed the 'mis-education of Generation M' (p.158)." Contrary to the misgivings held by some practitioners and academics, recent studies strongly indicate that the use of social networking sites have been instrumental to an increase in student high performance and collaborative efforts. Increasingly, students and faculty agree that electronic media and social netowking sites contribute largely to learning and productive engagements among learners (Selwyn, 2009; Genova, 2009; Hathi, 2008). While Selwyn uncovers specific features of social networking that impact existing instructional content and methodology, the enthusiasm with which students have embraced it by far compensates for the deficiencies and challenges inherent in the system.

\section{Electronic Media and Social Networking System}

At a recent end-of-the-year faculty retreat of a major historical black university, much emphasis was placed on teaching effectiveness, student learning outcomes, faculty teaching strategies and practices, and assurance of learning. These topics generated intense and prolonged discussions and debate among faculty participants and a number them were keenly interested in the instructional quality issues, specifically assurance of students' learning and effective teaching techniques. Interestingly, everyone felt the urgent need about staying current in teaching techniques and ensuring competitive students' learning outcomes. The interest in investigating the benefits and drawbacks of integrating electronic media and social networking in teaching communication and related business courses was driven by the mixed feelings and reviews provided by students and other academics.

The need for this paper was further motivated by the interest to establish an understanding of the role of electronic media and social networking in teaching communication skills, practices, and strategies in business organizations. These skills include interpersonal and team work, data collection and analysis, decision-making techniques, and computer and electronic media competencies. These basic skills are needed to work effectively in domestic and global business organizations and students are expected to acquire them in order to increase their competitive ability. Additionally, students should take a range of communication courses in business schools and should be able to demonstrate knowledge and ability in oral and writing communication, as well as intercultural competency. Other motivations for this paper were to determine whether or not social networking tools and electronic media have a significant impact on the quality of teaching as well as on faculty-student pedagogical relationships. Zhao \& Kuh (2004) noted that electronic social networks are effective and sophisticated tools that allow faculty members to be more interactive and engaging in their classrooms. In many classrooms, students find the experience of electronic interactions exciting, a source of fun, and an avenue for collaborative work with peers or classmates.

The author of this paper has systematically worked social media into class over the past three semesters, and business communication course content and objectives have been redesigned and expanded, requiring much students-faculty interaction. Electronic media and social networking sites have been integrated to enhance course materials and closely monitor students' research projects and other writing assignments. The entire course sequence and activities are divided into two overlapping phases, consisting of fundamental levels content activity and smallgroup work. In the first phase, students are taught in a hybrid format that involves face-to-face introductory and foundational lectures, conceptual definitions, course-specific vocabulary delineation, as well as mastery of presentation format in preparation for the mid-term examination. Subsequently, in phase two of the course work, students are prepared for the final examination and group projects. Various homework assignments, consisting of case analyses, team work, library/data base searches, planning and writing business messages, are assigned via Blackboard and Facebook. In these electronic media assignments, participation and feedback are highly required and 10-15 points are assessed for the quality of students' participation, which is measured by the number of constructive and consecutive responses and answers, and for timely submission of individual and group projects. Since the integration of this system of teaching in business communication classes, participation and responses via Facebook and Blackboard have accelerated and have also increased students' interest in homework assignments. Discussing the role of social networking technologies, Warren (2010) explained that among the channels in the system, Facebook has been extremely effective in disseminating information to students, colleagues, and friends. It facilitates social and academic communication, interaction in a "trusted environment," and provides a global context and impact. As Table 1 indicates, social networking has affected many aspects of the contemporary world, specifically education and business, via the Facebook system. A unique feature of social networking is the capability to facilitate immediate engagement between students and instructors and among students (Mason \& 
Rennie, 2008; Okoro, Cardon, \& Washington, 2011). It is well noted that globalization has tremendous impact on modern societies and workplaces and through the Internet/Facebook systems, teaching and learning, as well as professional activities, have expanded profitably.

Table 1 provides an analysis of users in various regions of the world, including the percentage of penetration. Certainly, social networking and electronic communication channels have gained more ground in Asia and Europe as the users range in millions. Other parts of the world are beginning to appreciate the process and usage rate is growing as well.

Table 1: Social Networking and Teaching

\begin{tabular}{|l|c|c|}
\hline \multicolumn{1}{|c|}{ Region } & Number (millions of users) & \% Regional Penetration \\
\hline Asia & 704.2 & 18.5 \\
Europe & 402.4 & 50.1 \\
North America & 251.7 & 73.9 \\
Latin America/Caribbean & 175.8 & 30 \\
Africa & 65.9 & 6.7 \\
Middle East & 48 & 23.7 \\
Oceania/Australia & 20.8 & 60.1 \\
World Average & & 24.7 \\
\hline
\end{tabular}

Source: Shona Leitch \& Mathew Warren (2011).

As Table 1 demonstrates, in recent years, the use of social networking has varied among nations, organizations, and stakeholders. The use has dramatically increased in some nations and continents, while in others the diffusion is very gradual because of varying degrees of technological sophistication. Users of electronic communication in Asia and Europe far exceed users in other places.

\section{SOCIAL NETWORKING AND ELECTRONIC COMMUNICATION: COSTS-BENEFITS}

The following questions guided the assessment of the role, effectiveness, advantages, and drawbacks associated with social networking and electronic media in teaching and learning business communication: (a) What are the costs and benefits of electronic media and social networking in teaching business communication? (b) How can electronic media and social networking improve teaching and learning of business communication? Studies (Mason \& Rennie, 2008; Hathi, 2008) indicate that experiences gained from teaching courses via electronic media have been both challenging and enriching. First, students establish good friendship, build interpersonal relationships, and interact constantly among themselves. Second, students become partners in creative problemsolving. Some students, especially those from other cultures who were reluctant or even uncomfortable to participate in class discussions as a result of personal, social, and cultural differences, could submit their assignments through the Blackboard system. Evidently, as Young (2002) noted, this group of students provided constructive and appropriate feedback and responses to questions which reflected a good understanding of content and context of reading assignments and projects discussed in class.

Independent of each other, authors Cohen (1994) and Bambina (2007) indicate that a constant challenge in using electronic media and social networking to facilitate teaching a course is responsible for students' increased rate of absenteeism and truancy and their inability to submit assignments that reflected their own efforts. Social networking supports team efforts and team development, but it affects students' independent work, self-reliance, and creative endeavors. Evidently, some specific writing assignments in business communications require students to think and work independently, but there are some students whose homework assignments or class projects they posted on Blackboard or Facebook do not indicate individual conduct or performance. Studies conducted over different times (Sproull \& Kiesler, 1986; Leah, 1992; Arieanna, 2007) indicate that heavy dependence on collaborative work compromises students' ability, initiative, and integrity. As a result, students are asked to present selected homework assignments during face-to-face class sessions in order to validate or substantiate the assignments that were submitted electronically. This is one of the ways to differentiate between assignments that were done independently and those that were collaborative. 


\section{CURRENT TRENDS AND GROWTH OF SOCIAL NETWORKING}

Some studies (Mason \& Rennie; Leith \& Warren, 200b; Warren, 2010) have noted that in recent years, social networking and electronic media have revolutionized the processes of teaching and learning and have created new challenges and opportunities in higher education teaching and learning. Both faculty members and students have discussed the costs and benefits of this innovative classroom instructional method and learning process (Hakane, Bakker, and Scaufeli, 2006). This method of learning challenges students' ability to manage their time and to work independently and collaboratively with integrity. Furthermore, the widespread impact of the Internet is felt in many parts of the global society in business transactions, educational learning, and social interactions. Notably, a critical feature of the electronic channels is the capability to establish and encourage constant and instantaneous engagements and interactions among people, academic institutions, and business organizations located in different parts of the world. Mason \& Rennie (2008) emphasized that in educational environments, communication between students and faculty members is of paramount importance in ensuring accountability and responsiveness, and they argue that social networking has been immensely instrumental in achieving both short and long-term academic objectives and goals.

Studies of recent years note that technological and media environment of the twenty-first century largely affect and enhance business operations and academic activities. The impact appears more pronounced in higher education where the process of teaching and learning has taken new directions. Indeed, the competitive positioning of academic institutions has increased the value of social networking in teaching and learning. Baird \& Fisher (2006), explaining the advantages associated with social networking in educational planning and design, stressed that in some universities, some courses are taught hybrid (face-to-face and web-enhanced) as well as completely online applications, which has provided tremendous learning opportunities to students and faculty. In addition, Wandel (2007) noted that a critical technological innovation in the educational system around the world in the first decade of the twenty-first century is the introduction of online social network sites, electronic media, and public websites. These developments in academe promote individual and group interactions and collaboration on important projects where individual skills and abilities are needed. Further, it fosters socialization, as well as immediate feedback mechanism, for quality of learning control and assurance. Baird \& Fisher (2006) and Wandel (2007) evaluated the effect of social networking in the teaching environment and determined that sites, such as Friendster, MySpace, and Facebook, which are important at college and university levels, enable students to communicate more effectively with one another, discuss academic and social matters, and engage in rigorous and productive group projects.

\section{Strengths of Electronic Media and Social Networking In Business Education}

Numerous theoretical and empirical studies spanning over decades on social networking sites and electronic media in higher education strongly indicate that the system has become increasingly significant in eduating present and future students. For example, in a 2007 study by the PEW Internet and American life Project, it was stated that more than half of all online teens use social networking. This national study of youth ages 12-17 reported that 55 percent use social networking sites and that 48 percent visit the sites daily or more often. Most respondents (91 percent) indicated that the sites were effective ways to connect and stay in touch with friends they see face-to-face. Although social networking sites have been criticized for allowing hormones to flair with racy photographs, sexy dialogue, and incriminating evidence of alcohol consumption and illegal drug use (Shropshire, 2006; Young, 2006), faculty members, administrators, and staff are constantly using these sites to reach or communicate with their students, mentees, and advisees (Wandel, 2007). Recent scholarly works have explained that the Internet/social media has the potential to make teaching and learning more effective and productive. Santovec (2006) described electronic media as a critical strategy for engaging students in classes, citing Florida's Rollins College, Pennsylvania's Mansfield University, and the University of Alabama as taking advantage of social networking sites in communicating with students about academic matters. The author further noted that faculty members at Capital University in Columbus, Ohio, established a social networking site for students interested in planning and developing an internship experience. Additionally, Arieanna (2007) highlighted social networking educational benefits and cited a survey commissioned by the National School Boards Association (NSBA) that demonstrated that $50 \%$ of students discuss, with classmates, their school work online (IM, blog or social networking sites) or via text message. The survey indicated that a large proportion (60\%) of students said they discuss 
education-related topics, such as college and career planning, and $96 \%$ of them stated that access to networking sites is helpful in cultivating and expanding social and friendship networks on campus and with students at other campuses. The study then concludes that social networking and communications media provide students the flexibility to learn anytime and anywhere, study at a convenient pace and time, have the opportunity to brainstorm with classmates, and devote more time on collaborative assignments.

Stressing that students world-wide value the advent of social networking sites and the use of electronic media as a conduit, Thompson (2007) surveyed students who reported preferences for the application of information technology by faculty members, which is consistent with other studies on social networking (Selwyn, 2009; Madge, Wellens, and Hooley, 2009) that sustainability of the interest in learning for Generation M would involve the integration of information technology into pedagogical practices and strategies. The authors noted that students at various universities exchange information regarding reading assignments, course selections, preparation for tests and examinations, and missed assignments. Fundamentally, the social network sites have expanded students' support systems, increased their interest in team work, and enhanced dependability on one another.

\section{Recurrent Issues in Social Networking and Electronic Channels in Business Education Instructions}

Past studies demonstrate divergent views on the effectiveness of social networking in preparing students for acquiring essential communication skills for global workplaces. For example, Sproull \& Kiesler (1986) and Lea (1992) indicate that electronic media and social networking or computer-mediated communications create inadequate or sub-standard educational exchange because of the impersonal structure associated with teaching via technological tools. Nie (2001) shares the concern that extensive use of the Internet or electronic media in teaching minimizes the critical role of face-to-face interactions with students in class sessions. Faculty members' ability to monitor or supervise social network activities is tasking and time-consuming and grossly affects content mastery and intellectual performance. Additional drawbacks of electronic social networks include students' low and inconsistent online participation, poor attendance, and inability to understand and comply with instructions for completing assignments. Consistent with the preceding views, Zhao \& Kuh (2004) summarized students' apprehension about safety, privacy, and ethic standards while in an online environment or using the social networking system.

\section{CONCLUSION AND RECOMMENDATION}

Present and past studies have demonstrated that electronic media and social networks can improve teaching and learning by monitoring or tracking the activities of both students and faculty members. Specifically, the effectiveness and efficiency of students' learning engagement and class participation can be measured by using electronic marking and feedback device (Bambina, 2007). To achieve a maximum level of participation and interaction, faculty members should organize students in small groups, assign points for relevant comments and discussion electronically, and should provide immediate feedback via electronic communication in order to hold students accountable. Conversely, Wellman, Witte, \& Hampton (2001) cautioned that the electronic media should be used in a form that does not intimidate students or make them uncomfortable about learning assigned materials. When students are comfortable or relaxed in a learning environment, they will be able to identify and write appropriate answers and responses to questions, which is particularly important for those students who find face-toface interactions exceedingly difficult.

For maximum productivity, it is important to use communication technologies to augment and compliment rich, face-to-face communication and for the development of excellent interpersonal communication skills. As Cardon \& Okoro (2011) indicated, technological tools (electronic media) should not be used to substitute for interpersonal communication. Rather, they should be used to complement face-to-face lectures and discussions. Extensive use of electronic media in teaching will affect interpersonal skills development. Indeed, students will not be adequately prepared for the workplace where interpersonal skills and oral presentation are critically important. The demand for strong interpersonal communication skills is as important as ever. For example, in presenting via PowerPoint, students should not use it as "a crutch" in their presentations. In other words, students should use PowerPoint to supplement their presentation, but not depend largely on it. As useful as electronic media and social networking tools have been, students should be reminded that they are the focus in a communication context. 
Therefore, faculty use of the electronic media should be strategically integrated to enhance the acquisition of fundamental communication skills and competencies.

\section{AUTHOR INFORMATION}

Ephraim A. Okoro, Ph.D. is an assistant professor of business communication and marketing at Howard University. His research interests probe the interface between intercultural communication and workforce diversity in the context of globalization. He teaches business communication, marketing communication, management communication, and principles of marketing. Address correspondence to Dr. Ephraim Okoro, Department of Marketing, School of Business, Howard University, 2600 - Sixth Street, NW, Washington, D.C. 20059; E-mail: eaokoro@howard.edu. (202) 806-1545

\section{REFERENCES}

1. Arieanna (2007, August 21). Educational benefits of social networking. Education week.

2. Baird, E.E., \& Fisher, M. (2006). Neomillenial user experience design strategies: Utilizing social networking media to support "always on" learning styles. Journal of educational technology systems, 34(1), 5-32.

3. Bambina, A (2007). Online social support: The interplay of social networks and computer-mediated communication. Amherst, NY: Cambria Press.

4. Okoro, E., Cardon, P., \& Washington, M. (2011, September). "E-Portfolios in business communication courses as tools for employment." Business Communication Quarterly.

5. Cardon, P. \& Okoro, E. (2010 December). A measured approach to adopting new media in the business communications classroom." Business Communication Quarterly, 73(4), 434-438.

6. Cohen, E.G. (1994). Structuring the classroom: Conditions for productive small groups. Review of Educational Research, 64(1), 1-35.

7. Genova, G. L. (2009, March). No place to play: Current employee privacy rights in SNS. Business Communication Quarterly (97-101).

8. Hakanen, J., Bakker, A., Scaufeli, W. (2006). Burnout and work engagement among teachers. Journal of School Psychology, 43(6), 495-513

9. Hathi, S. (2008, February/March). Billions lost from social networking. Strategic Communication. Vol. 12 (2).

10. Lea, M. (ed.). (1992). Contexts of computer-mediated communication. Harvester-Wheatsheaf, New York.

11. Leith, S., Warren, M. (2008b). Analyzing online teaching and learning systems using MEAD. Interdisciplinary Journal of E-Learning and Learning Objects, 4, 259-267. Retrieved from Http://.ijello.org/volume 4/IJELLOv4p259-267Leitch497.pdf

12. Madge, C. Meek, J., \& Hooley, T. (2009, June). Facebook, social integration, and informal learning at University: It is more for socializing and talking to friends about work than for actually doing work. Learning, Media and Technology, Volume 34, Number 2 (141-155).

13. Mason, R., \& Rennie, F. (2008). Learning and social networking handbook: Resources for higher education. USA: Routledge.

14. Nie, H.H. (2001). Sociability, interpersonal relations, and the Internet: Reconciling conflicting findings. American Behavioral Scientist, 45 (3), 420-435.

15. Santovec, M.L. (2006, March). Using online networking to engage and retain students. Recruitment and retention in higher education, 20 (3), 1, 3, 7 5. Academic Search Premiere.

16. Selwyn, N. (2009, June). Faceworking: Exploring students' education-related use of Facebook. Learning Media and Technology, Volume 34, No2, (157-174)

17. Shropshire, C. (2006, September 29). Facebook faces uncertainty. Pittsburgh post gazette. www.postgzeette.com/pg/06272/725984-96.stm

18. Sproull, L., Kiesler, S. (1986). Reducing social context cues: Electronic mail in organizational computing. Management sciences, 32 (11), 1492-1512

19. Suskie, L. (2004). Assessing student learning: A common sense guide. Boston, MA. Anker.

20. Wandel, T. (2007, July). About Facebook: Educational institution responses to online social networking. WCA Conference, Brisbane. 
21. Warren, M. (2010). Security risks of social networking systems (Keynote Presentation), $4^{\text {th }}$ IEE International Conference on Network and Systems Security, Melbourne, Australia.

22. Leitch, S. \& Warren, M.J. (2011). Social networking and teaching: An Australian case study. Proceedings of Informing Science and IT Education Conference, Victoria, Australia.

23. Young, J. (2002, February 21). Creating online portfolios can help students see 'Big Picture,' colleges say. Chronicle of Higher Education, http://chronicle.com/ free/200202210t.htm.

24. Young, J.R. (2006, August 4). Facebook and other social networking sites raise questions for administrators. Chronicle of higher education, 52 (48), Academic Search Premiere.

25. Zhao, C. \& Kuh, G. (2004). Adding value: Learning communities and student engagement, Research in Higher Education, 45 (2), 115-138. 
NOTES 